DHI, 1991: Technology assessment for arctic offshore oil production; applied to Greenland. Report by Arctic Consultant Group A/S \& Danish Hydraulic Institute, 303 pp.

DMI, 1966-1981: The ice conditions in the Greenland waters, 1966-1981. Annual publications 1966-1981. Danish Meteorological Institute, Copenhagen, Denmark.

DMI, 1976: West ice investigations. Part I. West ice histograms 1959-1974. Danish Meteorological Institute, Nautical Department, $204 \mathrm{pp}$.

GTO, 1979a: Environmental conditions offshore West Greenland Vol. I. Summary, Data bank contents. Report from Danish Hydraulic Institute under contract for Greenland Technical Organization, 101 pp.

GTO, 1979b: Environmental conditions offshore West Greenland Vol. IV. Icebergs. Report from Danish Hydraulic In- stitute under contract for Greenland Technical Organization, $158 \mathrm{pp}$.

Nielsen, A. H., Dietrich, J. \& Fabricius, J. S. 1978: Environmental conditions on the continental shelf off West Greenland. J. Petrol. Techn. 30, 1381-1391.

Thomsen, H. H. 1992: Ice conditions offshore West Greenland - an introduction (enclosure 5). In Offshore West Greenland - Exploration Information 1992. Unpubl. intern. GGU rep., $11 \mathrm{pp}$.

Wadhams, P. 1981: The ice cover in the Greenland and Norwegian Seas. Rev. Geophys. Space Phys. 19, 345-393.

H. H. T., Geological Survey of Greenland, Copenhagen.

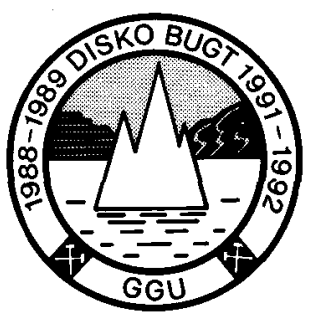

\title{
Disko Bugt Project 1992, West Greenland
}

\author{
Flemming G. Christiansen
}

One of GGU's major field activities in 1992 took place in July and August in the Disko-Nuussuaq-Svartenhuk Halvø area of central West Greenland. This was the fourth and final year of field studies under the 'Disko Bugt Project', carried out from 1988-1992 with one summer's break in 1990.

The Disko Bugt Project includes a large number of activities, essentially within two very different geological provinces: the Archaean-Proterozoic basement and supracrustal province, and the onshore part of the Cretaceous-Tertiary sedimentary and volcanic basin. The Precambrian basement is mainly exposed towards the east, and the sediments and volcanic rocks mainly towards the west (Fig. 1).

The main aims of the Disko Bugt Project are to assess the resource potential of the region with respect to minerals (mainly in the Precambrian supracrustal rocks) and hydrocarbons (in the neighbouring offshore basins).

During the previous three field seasons the base camp was situated at the abandoned settlement Ataa (Fig. 1), and work was concentrated on the basement and supracrustal rocks on Arveprinsen Ejland and the areas towards the east and north-east (see Kalsbeek, 1989, 1990; Kalsbeek \& Christiansen, 1992). This work was completed in 1991 with the exception of studies of the mineral potential of the Lower Proterozoic Karrat Group (Thomassen, 1992). In 1992 the headquarters of the expedition was the town of Uummannaq and field work focused on the sedimentary and volcanic succession on Nuussuaq and Svartenhuk Halvø and included a shallow core drilling campaign. Studies of the volcanic rocks are a continuation of a long-term research programme whereas the sedimentary basin studies were more extensive in 1992 than in previous years (see overview in Christiansen et al., 1992 and Kalsbeek \& Christiansen, 1992).

The Disko Bugt Project is being carried out as a collaboration between GGU and scientists and students from a number of other institutions and universities. In 
199216 geologists and M.Sc. students and 8 technical staff (including drilling and helicopter personnel) took part in the expedition. There was also logistic collaboration with the two mining companies operating in the area, Platinova $\mathrm{A} / \mathrm{S}$ and Falconbridge Ltd.

\section{Precambrian supracrustal rocks - mineral potential}

The Lower Proterozoic Karrat Group is the most extensive supracrustal belt in West Greenland, but the assessment of its mineral potential is still in an early phase. There are indications of three main types of mineralisation occurring in the Karrat Group: (1) carbonate-hosted lead-zinc deposits; (2) shale-hosted massive base metal sulphides; and (3) gold-bearing quartz veins (Thomassen, 1992).

The first type is known from the now exhausted Black Angel Mine in Maarmorilik and a number of other occurrences in the southern carbonate-dominated part of the supracrustal belt, and has been the main target for exploration over the last few decades (Thomassen, 1991).

The second type is known from the siliciclastic units in the central and northern part of the supracrustal belt; however, exploration has so far been limited. The existence of the third type is based on boulder finds and geochemical anomalies, and mineralisation is suspected to occur in turbidite-hosted quartz veins and shear zones (Thomassen, 1992).

The supracrustal succession was sampled from four camps east and west of the Inngia peninsula (Fig. 1). The programme comprised general prospecting, stream sediment sampling and panning of heavy mineral concentrates in order to establish the extent of previously recognised anomalies.

\section{Cretaceous and Tertiary sediments - hydrocarbon potential}

As a consequence of renewed interest in petroleum exploration offshore West Greenland (Christiansen \& Pulvertaft, 1992) new studies of the Upper Cretaceous Lower Tertiary sediments exposed on Disko, Nuussuaq and Svartenhuk Halvø (Fig. 1) were begun in 1991 (Christiansen et al., 1992). The petroleum geological field work includes detailed sedimentological studies, sampling for palynological and organic geochemical analysis, mapping and structural analysis, and in 1992 a drilling programme was also included. Three students collected sample material for their M.Sc. theses on provenance and diagenesis of sandstones and on the geochemistry of auto-combusted shales.
The non-marine Cretaceous succession was studied as part of a Ph.D. project supported by the University of Copenhagen and the Danish Natural Science Research Council. The study area includes the north coast of Nuussuaq and Upernivik $\emptyset$ (Fig. 1). Field work in 1992 focused on the relationships between palaeotopography of the deeply weathered basement and the fluvial sediments, mapping of sedimentary sequences and palaeocurrent analyses. Sedimentary facies were studied with special emphasis on the palaeoenvironmental significance of coal seams.

The Upper Cretaceous fluvio-deltaic Atane Formation was studied in the Aaffarsuaq valley in the central part of Nuussuaq (Fig. 1). The field work was a follow-up of previous studies (e.g. Pedersen, 1989; Pedersen \& Pulvertaft, 1992), and in 1992 studies concentrated on the lateral facies changes as the Atane Formation is traced towards the north and west where the degree of marine influence increases. In this area the Atane Formation is well exposed in many stream sections and is dominated by delta front deposits. These are locally intensely bioturbated showing that the muddy and fine-grained sand bottom supported a rich fauna. A few invertebrates were also found and these samples are being examined for marine microfossils. In the gullies on the north side of Aaffarsuaq the Atane Formation is erosively overlain by dark grey shales with thin turbiditic sandstones which locally contain large inocerams.

Studies of Upper Cretaceous - Tertiary submarine fan sediments were continued in 1992; they were initiated in 1991 and are partly funded by the Carlsberg Foundation. Emphasis has been placed on a detailed sedimentological analysis of the late Maastrichtian palaeovalley systems found in the Kangilia Formation and the middle to late Paleocene Quikavsak Member on the south coast of Nuussuaq, in order to place them within a regional tectonic and sequence stratigraphic framework.

\section{Drilling programme}

The drilling programme was carried out with a helicopter-portable unit (Fig. 2). This unit operates with a wire-line system giving a hole diameter of $46 \mathrm{~mm}$ and a core diameter of $30 \mathrm{~mm}$.

A total of 12 holes were drilled to depths between 45 $\mathrm{m}$ and $83 \mathrm{~m}$ (average $67 \mathrm{~m}$ ) with a cumulative length of $807 \mathrm{~m}$ (Table 1). Core recovery was almost complete in all of the holes, although the core quality was often very poor in the top $20 \mathrm{~m}$ due to extensive fracturing.

All cores were described at the drill site and gamma ray logs were run in most of the holes. Small core pieces 


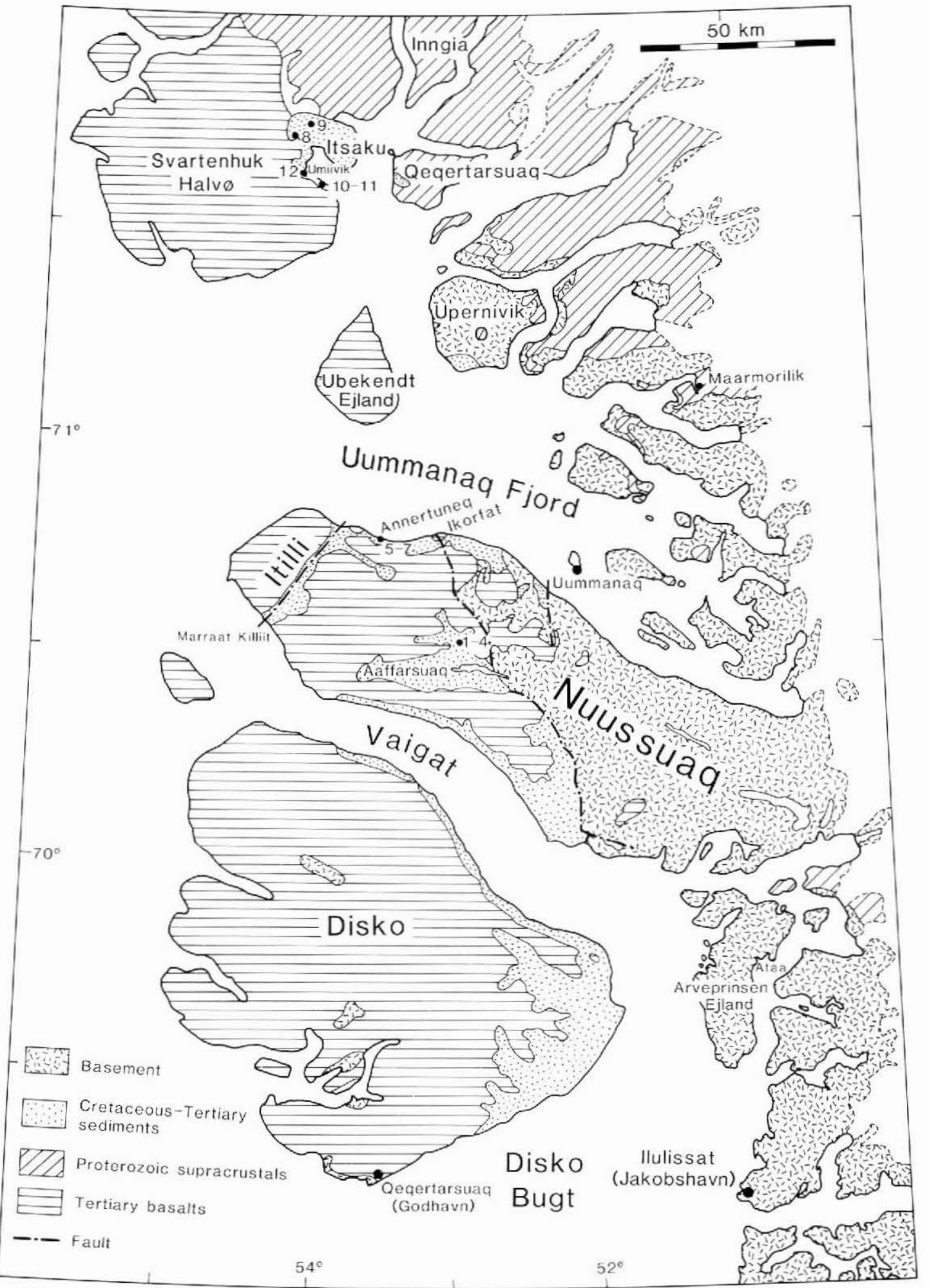

Fig. 1. The Disko Bugt region and areas to the north; Precambrian basement in the east and the onshore part of the Cretaceous-Tertiary West Greenland basin in the west. Numbers 1-12 denote drill sites of GGU wells 400701-400712. 


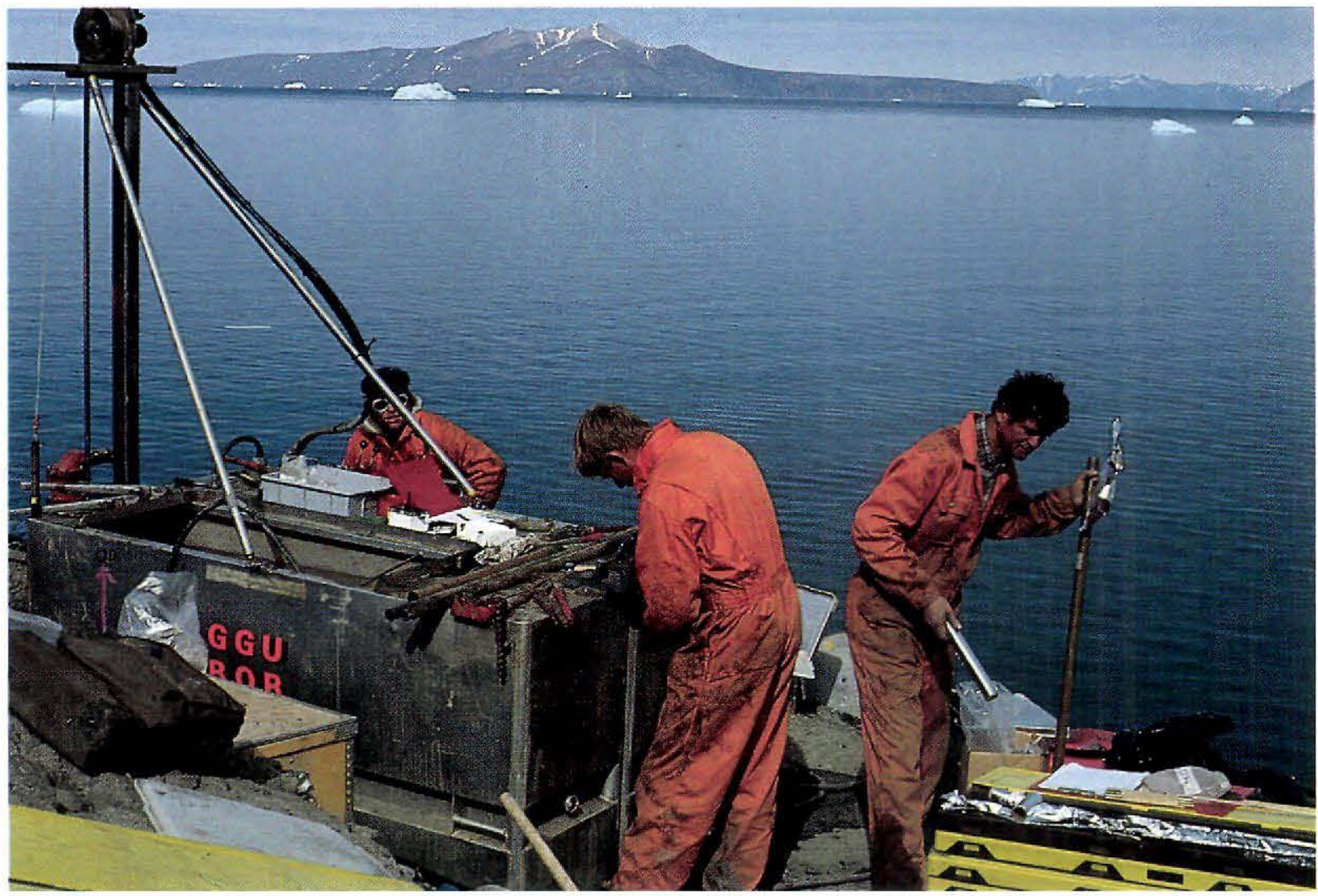

Fig. 2. Drilling team on the north coast of Nuussuaq.

$(5-10 \mathrm{~cm})$ were canned at the drill sites for analysis of light hydrocarbons (C1-C8), typically at 5 to $10 \mathrm{~m}$ intervals.

The first four holes (400701-400704) were located in Agatdalen (Fig. 1, Table 1). Together the four holes represent a significant part of the marine Cretaceous succession in the Agatdalen area and include all major facies types (mainly mudstone and sandy mudstone). The boundary with the underlying Atane Formation has been cored.

Three holes (400705-400707) were located on the north coast of Nuussuaq at Annertuneq (Figs 1, 3, Table 1). The cores from these three holes span about $250 \mathrm{~m}$ of Upper Campanian-Maastrichtian mudstones. The top of the uppermost hole is situated approximately 100 $\mathrm{m}$ below the base of a submarine fan cobble and boulder conglomerate which has previously been described as basal Danian but has now been shown to be Late Maastrichtian (see Christiansen et al., 1992; Nøhr-Hansen, 1993). The lowermost hole terminated about $35 \mathrm{~m}$ below sea-level.

The remaining five holes (400708-400712) were all on Svartenhuk Halv $\emptyset$. Hole 400708 was drilled in the pre-
Table 1. Shallow drill sites for source rock studies

\begin{tabular}{lccccrl}
\hline $\begin{array}{l}\text { GGU } \\
\text { no. }\end{array}$ & Date & $\begin{array}{c}\text { Depth } \\
\mathrm{m}\end{array}$ & Log & Locality & $\begin{array}{c}\text { Alt. } \\
\mathrm{m}\end{array}$ & Unit \\
\hline 400701 & $07.7-08.7$ & 44.98 & - & Agatdalen & 420 & Marine Cret. \\
400702 & $10.7-11.7$ & 65.48 & ok & Agatdalen & 387 & Marine Cret. \\
400703 & $15.7-16.7$ & 72.39 & ok & Agatdalen & 363 & Marine Cret. \\
400704 & $18.7-19.7$ & 82.91 & ok & Agatdalen & 346 & Marine Cret. \\
400705 & $24.7-26.7$ & 47.09 & ok & Annertuneq & 175 & Marine Cret. \\
400706 & $27.7-28.7$ & 63.23 & & Annertuneq & 125 & Marine Cret. \\
400707 & $01.8-02.8$ & 64.63 & ok & Annertuneq & 30 & Marine Cret. \\
400708 & $06.8-07.8$ & 78.70 & ok & Svartenhuk & 125 & Marine Cret. \\
400709 & $10.8-12.8$ & 86.24 & ok & Svartenhuk & 50 & Marine Cret. \\
400710 & $15.8-16.8$ & 66.23 & - & Svartenhuk & 157 & Marine Cret. \\
400711 & $17.8-18.8$ & 54.55 & ok & Svartenhuk & 95 & Marine Cret. \\
400712 & $20.8-21.8$ & 80.48 & - & Svartenhuk & 5 & Marine Cret. \\
\hline
\end{tabular}

sumed oldest exposed marine sediments, on a locality where Turonian ammonites have previously been discovered. Hole 400709 was drilled into more or less equivalent strata but is more proximal to the basement and exposed non-marine sediments. Holes 400710 and 400711 were situated fairly close to each other, and 


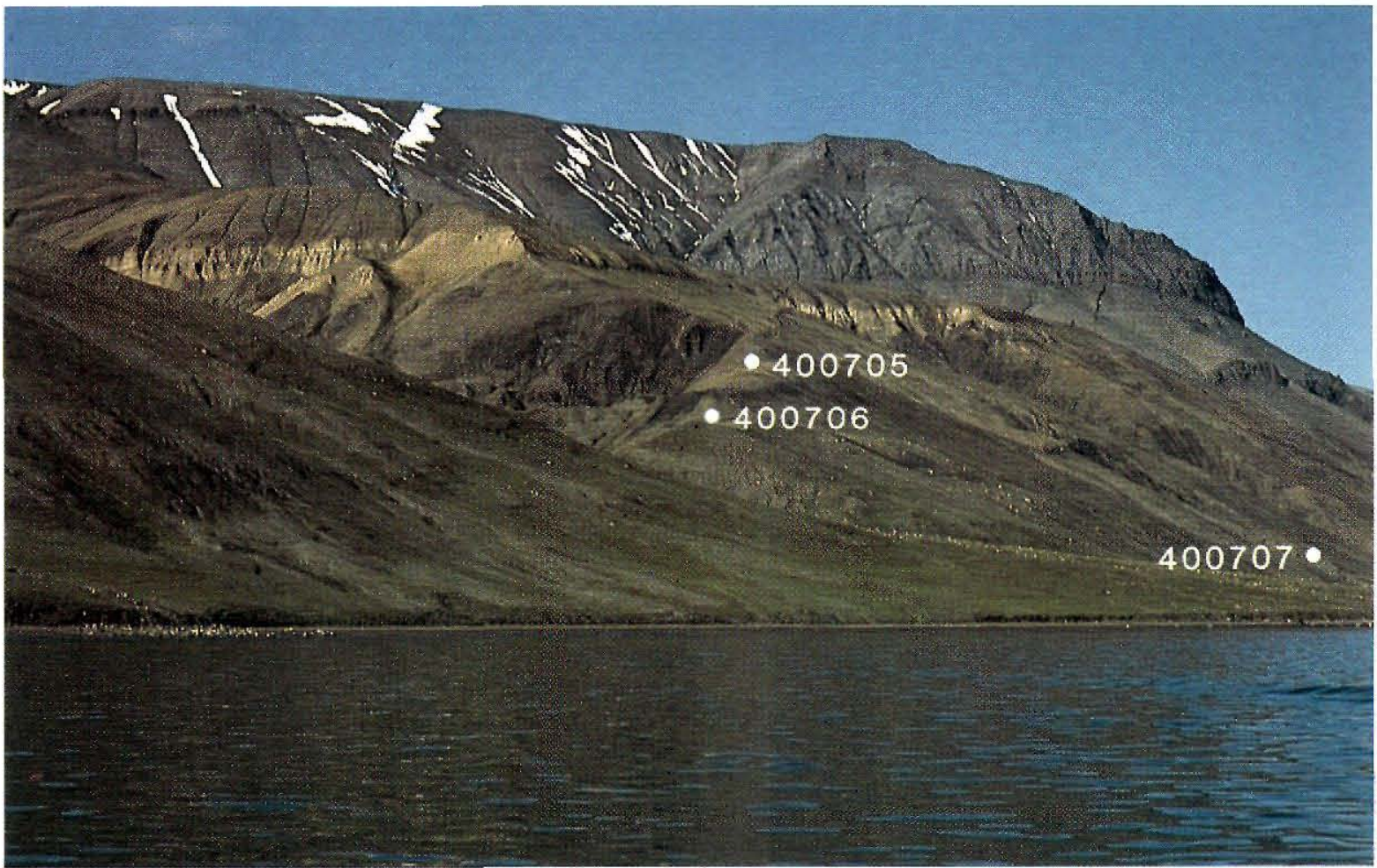

Fig. 3. Location of the drill sites at Annertuneq on the north coast of Nuussuaq below the impressive conglomerate.

together they represent most of the Coniacian-Maastrichtian succession well known in the Umiivik area. Hole 400712 was drilled at a Coniacian ammonite locality close to sea-level at Umiivik (Fig. 1) (corresponding to loc. 6 in fig. 2 of Birkelund, 1965). This hole terminated in black mudstone more than $70 \mathrm{~m}$ below sealevel (Table 1). Further information and data on the cores are given by Christiansen et al. (in press).

\section{Recognition of hydrocarbon seepage}

Although the detailed studies and drilling in the Cretaceous-Tertiary succession provide important information on sedimentology, stratigraphy and organic geochemistry - three important disciplines in petroleum exploration - additional methods must be applied for direct recognition of hydrocarbon generation in the subsurface. As in other onshore sedimentary basins in Greenland, considerable time has been devoted to searches for seeps or impregnations of petroleum (Christiansen, unpublished) and gas seepage from lakes and mud volcanoes (see Henderson, 1969, for early descriptions from West Greenland).

A significant discovery of petroleum-impregnated basalt was made on the south-west coast of Nuussuaq near Marraat Killiit (Fig. 1), only a few kilometres from a previously described locality preserving highly coalified bitumen (Pedersen, 1986). In the new showing most of the hydrocarbons have survived both thermal alteration and biodegradation (only evidence of moderate evaporation of lighter compounds). Analyses by gas chromatography and mass spectrometry show the presence of oleanane which is only found in Tertiary oils and source rocks dominated by terrestrially derived organic matter, e.g. in deltaic successions (F. G. Christiansen and others, GGU, unpublished data). This discovery proves the existence of a source rock for liquid hydrocarbons in the West Greenland basin and opens up the possibility of new play concepts in addition to the Cretaceous types that have been advocated by Chalmers et al. (in press) and during the promotion of the West Greenland licensing round (Christiansen et al., this report).

\section{Tertiary volcanics}

The Cretaceous - Lower Tertiary sediments in West Greenland are overlain by a thick Tertiary volcanic succession that is well exposed in large, often almost in- 
accessible areas on Disko, Nuussuaq and Svartenhuk Halvø (Fig. 1). This outcrop pattern has made studies in the past few decades very time-consuming, but new photogrammetric techniques now make it possible to prepare very precise geological maps and sections in the laboratory (cf. Dueholm \& Pedersen, 1992).

Oblique colour photographs were taken during extensive helicopter reconnaissance, and characteristic marker beds were traced (especially brownish sedimentcontaminated units) in western and northern Nuussuaq. The field work also involved detailed sampling and studies of sections in accessible areas. This also provides important structural data for the study of the Itilli and Ikorfat fault zones and the onlap of the basalts on the basement. Economically interesting accumulations of metallic iron and sulphides were found to be widespread in contaminated units at one stratigraphic level.

A separate study concerning the origin of glass spherules in tuffs from the sediments immediately below the Tertiary volcanics in Agatdalen was carried out by a team from the University of California, Berkeley. This study aimed at distinguishing between volcanic and meteorite impact origin.

\section{Future studies}

With the completion of the 1992 season, field work of the Disko Bugt Project has been brought to an end. It is, however, likely that detailed field studies will continue on specialised subjects depending on the results obtained from laboratory analyses of material collected.

The main aim of the sedimentary basin study is to integrate all multidisciplinary results within a sequence stratigraphic framework. Laboratory work on sediment samples and cores will concentrate on palynostratigraphic studies and organic geochemical analysis, first by screening, later by detailed gas chromatography and mass spectrometry. This will provide data on age, depositional environment, petroleum potential and thermal maturity of the mudstones, and together with sedimentological models predict the distribution of potential reservoir and source rocks in the adjacent offshore basins.

Acknowledgements. The studies of the Cretaceous sediments are supported by the Danish Ministry of Energy through the project 'Kridtsedimenter, Vestgrønland' (Grant No. EFP 1313/ 91-0014). The work of Gregers Dam is funded by the Carlsberg Foundation (Grant No. 91-0244/20). Field work was also supported by the Danish Natural Science Research Council (Grant No. 11-9494-1 to Asger K. Pedersen and Gunver K. Pedersen and Grant No. 11-9714-1 to Helle H. Midtgaard).

Our friends in Uummannaq are thanked for their great help with logistics during the summer and for creating a happy working atmosphere.

\section{References}

Birkelund, T. 1965: Ammonites from the Upper Cretaceous of West Greenland. Bull. Grønlands geol. Unders. 56, 192 pp. Chalmers, J. A., Pulvertaft, T. C. R., Christiansen, F. G., Larsen, H. C., Laursen, K. H. \& Ottesen, T. G. in press: The southern West Greenland continental margin: rifting history, basin development, and petroleum potential. In Parker, J. R. (ed.) Proceedings, 4th conference of petroleum geology of NW Europe.

Christiansen, F. G. \& Pulvertaft, T. C. R. 1992: Petroleumgeological activities in 1991: reassessment of areas of earlier exploration, and improvement of information service to industry. Rapp. Grønlands geol. Unders. 155, 28-30.

Christiansen, F. G., Dam, G., McIntyre, D. J., Nøhr-Hansen, H., Pedersen, G. K. \& Sønderholm, M. 1992: Renewed petroleum geological studies onshore West Greenland. Rapp. Grønlands geol. Unders. 155, 31-35.

Christiansen, F. C., Dam, G., Nøhr-Hansen, H. \& Sønderholm, M. in press: Shallow core summary sheets: Cretaceous sediments of Nuussuaq and Svartenhuk Halvø (GGU 400701-400712). Open File Ser. Grønlands geol. Unders.

Dueholm, K. S. \& Pedersen, A. K. (ed.) 1992: Geological analysis and mapping using multi-model photogrammetry. Rapp. Grønlands geol. Unders. 156, 72 pp.

Henderson, G. 1969: Oil and gas prospects in the CretaceousTertiary basin of West Greenland. Rapp. Grønlands geol. Unders. 22, $63 \mathrm{pp}$.

Kalsbeek, F. 1989: GGU's expedition in the Disko Bugt area, 1988. Rapp. Grønlands geol. Unders. 145, 14-16.

Kalsbeek, F. 1990: Disko Bugt Project, central West Greenland. Rapp. Grønlands geol. Unders. 148, 21-24.

Kalsbeek, F. \& Christiansen, F. G. 1992: Disko Bugt Project 1991, West Greenland. Rapp. Grønlands geol. Unders. 155, 36-41.

Nøhr-Hansen, H. 1993: Upper Maastrichtian? - lower Paleocene dinoflagellate cysts and pollen from the turbidites in the Itilli region, Nuussuaq, central West Greenland - first dating of the sediments. Rapp. Gronlands geol. Unders. 159 (this volume).

Pedersen, A. K. 1986: Indication of migrated hydrocarbons in Tertiary volcanic rocks from western Nûgssuaq, central West Greenland. Rapp. Grønlands geol. Unders. 130, 32-35.

Pedersen, G. K. 1989: A fluvial-dominated delta in a volcanic province, W. Greenland. In Whateley, M. K. G. \& Pickering, K. T. (ed.) Deltas: sites and traps for fossil fuels. Spec. Publ. geol. Soc. Lond. 41, 139-146.

Pedersen, G. K. \& Pulvertaft, T. C. R. 1992: The non-marine Cretaceous of the West Greenland basin. Cretaceous Res. 13, 263-272.

Thomassen, B. 1991: The Black Angel lead-zinc mine 1973-90. Rapp. Grønlands geol. Unders. 152, 46-50.

Thomassen, B. 1992: The gold and base metal potential of the Lower Proterozoic Karrat Group, West Greenland. Rapp. Grønlands geol. Unders. 155, 57-66.

F. G. C., Geological Survey of Greenland, Copenhagen 